\title{
Medicinal and Aromatic Plants: A Growing Commercial Sector of Nepal
}

\author{
- Uday R. Sharma, Ph.D.*
}

The sector of Medicinal and Aromatic Plants (MAPs) is a growing commercial sector in Nepal. Out of 5856 flowering plants recorded in Nepal (HMGN 2002), 690 species are considered having medicinal properties (Malla and Shakya 1984). This number includes 510 species found in the wild in Nepal; 120 species are in cultivation or have become naturalized, and 60 species are exotic. A database maintained by a group of botanists and associated professionals, Medicinal \& Aromatic Plant Database of Nepal (MAPDON), has listed 1624 plant species as having medicinal use. This database also includes many exotic plants. Despite the efforts to conserve, 51 MAP species have been assigned to various threat categories as per the IUCN guidelines: 3 taxa as "critically endangered," 14 as "endangered," 23 as "vulnerable," 3 as "nearly threatened," 1 "of least concern," and 7 taxa as having "data deficient" (Shrestha and Joshi 1996; Bhattarai et al. 2002). Nepal's rich plant diversity is found in forests, pasturelands, meadows, traditional farms and wetlands. Because of the excellent network of protected areas in Nepal, comprising of 9 national parks, 4 reserves, 3 conservation areas, and 11 buffer zones, covering nearly 20 percent of the country's land, MAPs found within these 27 protected areas are relatively well protected and are not subjected to commercial harvest.

MAP is not a well defined term in literature. Any plant used in any type of medical system, such as Ayurvedic, Unani, Siddha, Tibetan, or in the ethnic healing system is generally categorized as medicinal plants. Aromatic plant is one having aroma in any of its parts. Categorization of plants as MAP is not always easy as plants tend to have at least some properties of medicinal value or have aroma. The term "Non-Timber Forest Product" NTFP (FAO uses the term "Non-Wood Forest Product") is also a frequently used term. This term is more inclusive, which includes MAPs, bamboo and rattan, nuts, fruits, wild vegetables, spices, pesticides, tannin, dyes, gums, resins and incense; it does not include timber and firewood. "Jadibuti" is also more frequently used term in Nepal, which is closer to MAPs in terms of its species listing. Jadibuti is a group of plants, whose part or the entire plant form ingredients in the preparation of Ayurvedic medicine. Nepal's jadibuti are listed in the Annex III of the Forest Regulations 2051 (HMGN 1995); the latest revision of the Annex is at its final stage of decision. It classifies 179 plant species into 207 categories based on the primary use of the parts of the plant: roots/rhizomes (46), barks (25), leaves and stems (29), flower and inflorence (15), fruits/seeds (63), gum/resin (8), and entire plants (21). The royalty rates are also given in this annex.

Forest law, especially the Forest Regulations 2051 (HMGN 1995), has made provision for common people to benefit from the NTFP found in forests in their neighbourhood. For forests which are managed directly by the District Forest Office (DFO), the office prepares harvest plan usually for five years based on the best available information about the NTFP resources found in their forest. The plan is submitted to the Forest Department for approval after conducting necessary environmental impact assessments mandated by the Environmental Protection Regulations 2054 (HMGN 1997). The annexes I and II of this Regulations specify the requirements of IEE (initial environmental examination) and EIA (environmental impact assessment) for activities requiring environmental clearance before undertaking those activities. Usually, MAPs collected from a district for a duration of one year of the amount 5-50 $\mathrm{m}$ tons (for plants harvested for barks or oil extracts $10-100 \mathrm{~m}$ tons) per species require IEE and the harvest level exceeding those limits requires EIA. For resin tapping from pines of any amount greater than $5 \mathrm{~m}$ tons/year/district, only IEE would be required (GON 2007).

The NTFPs approved for collection are offered by the DFO each year just before the collection season. Collection permits are issued based on first-come-first-served basis. Any Nepali is eligible to apply for collection permit, but usually local residents are given preference over the people residing outside the district. The competitive bidding for jadibuti, as for other resources listed under Annex VI of the same regulations is not required; and even VAT is

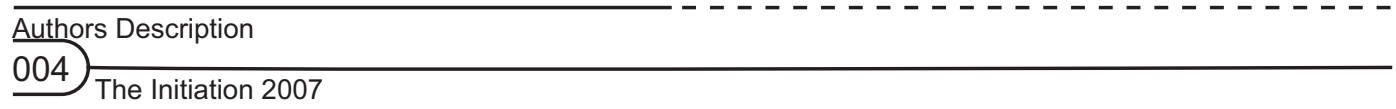


waived on their transaction. This provision provides easy access to the common people for collection of these valuable resources. The royalty rates are kept low and ranges from Rs. $0.25-10,000.00$ per $\mathrm{kg}$. The thumb rule for royalty fixation is to charge about 10 percent of the local market price, except in some cases the rates are kept deliberately high to discourage the collection in order to protect the plant from over-harvest or to facilitate legal procedure in the court for lawsuits related to restricted plants.

The sector of MAPs has been a vastly unexplored, under-utilized component of forestry in Nepal. For rural people, especially in the hills and Himals of Nepal, collection of herbs is an old practice to augment their sources of income, and it provides livelihood options for many people. They also provide the basic primary health care for a majority of rural population. These herbs are mostly exported out of the country in crude form and pass through series of middlemen. About 100 medicinal and aromatic plants are traded annually from Nepal (Amatya 2000). Among them 23 MAPs have been found traded in high volume (see Table 1). Often, market demands create pressure on wild collections causing important plants to become rarer; usually this situation is followed by the government imposing restrictions on their uses, collection or trade. This vicious cycle is not very helpful to both, the plant species concerned or the local communities who are benefiting from their collections. Because of poor law enforcement the bans are only for namesake and in many cases the restriction itself becomes a breeding ground for corruption. A case of Karnali is exemplary: Of the total benefit generated from the collection and trade of some medicinal plants, it was found, the primary collectors, Jumla based traders, and Nepalgunj based traders received unequal shares of benefits because of the government's restrictions on their collection. The restriction helped big traders to get larger share of benefits: Primary collectors got only $7 \%$ for restricted plants; whereas similar percentage for non-restricted plants was $11 \%$. The glaring difference was for the Nepalgunj based traders, who got $52 \%$ of the total benefit for restricted plants and only $12 \%$ for the non-restricted plants. For the Jumla based traders the proportion was $22 \%$ for restricted plants and $43 \%$ for non-restricted plants (CBED 1999).

The case of Yarsa Gumba (Cordyceps sinensis) further shows how restriction on plants can be harmful sometimes. It seems, relaxation of government restriction on Yarcha Gumba has boosted the local economy and gradually would bring the illegal market on the resources under control (Box 1).

\section{Box 1.Yarsa-Gumba emerging speciality commodity for Nepal.}

Y-G is a mushroom that comes out of the anterior end of a caterpillar during monsoon in the highland pastures of Nepal. The fungus that infects the caterpillar of Hepialus armoricana (a moth) is of the genus Cordyceps. The infected larvae wintering underground emerge outside after the snow melt. The caterpillar dies as the fungus grows and produces spores. The entire plant with the remains of caterpillar is consumed for vitality and vigour. Patented products, such as capsules, are brought out in China and USA and are capturing the attention of people, especially those who are suffering from chronic illness.

\begin{tabular}{|c|c|c|c|}
\hline Dates & $\begin{array}{l}\text { Government } \\
\text { Record of Harvest }\end{array}$ & $\begin{array}{l}\text { Revenue } \\
\text { Rs. }\end{array}$ & Restrictions \\
\hline 2058/9/16 (2001) & & & $\begin{array}{l}\text { Y-G was totally banned for collection, use, trade, } \\
\text { transportation, and export outside the country. } \\
\text { For penalty purpose the royalty was fixed at } \\
\text { Rs. } 500.00 \text { per piece. } 1 \mathrm{~kg} \text { of Y-G in air dry state, } \\
\text { depending on the size can count to } 3000-3300 \\
\text { The restriction was relaxed: Y-G could be exported } \\
\text { after processing in Nepal. The processing was } \\
\text { considered adequate if the product is steamed and } \\
\text { packaged. The royalty was fixed at Rs. } 20,000 / \mathrm{kg}\end{array}$ \\
\hline $\begin{array}{l}\text { FY 2059-2060 } \\
(2002 / 2003) \\
\text { FY 2060-2061 } \\
(2003 / 2004)\end{array}$ & $\begin{array}{l}4.5 \mathrm{~kg} \\
76.1 \mathrm{~kg}\end{array}$ & $\begin{array}{l}89,000 \\
1,372,000\end{array}$ & \\
\hline $\begin{array}{l}2061 / 6 / 18(2004) \\
\text { FY 2061-2062 } \\
(2004 / 2005)\end{array}$ & 12.6 kg & 252,000 & The restriction of processing was lifted. \\
\hline $\begin{array}{l}2062 / 6 / 10(2005) \\
\text { FY 2062-2063 } \\
(2005 / 2006)\end{array}$ & & & Royalty was reduced to Rs. $10,000 / \mathrm{kg}$ \\
\hline
\end{tabular}


The government has recently revised the restricted plant list and made it shorter. It includes few MAPs: Three species, Dactylorhiza hatgirea (Paanchaule), Juglans regia (Okhar), and Lichens spp. (Jhyaau) are completely banned for collection, transportation and trade. Shilajeet (rock exudates) and four species of plants, Nardostachys grandiflora (Jatamansi), Valeriana jatamansii (Sugandhawal), Abies spectabilis (Talispatra), and Taxus spp. (Lauth salla) are banned for export outside the country in raw form. Processing requirements are considered sufficient if the plant is converted into dry powder, essential oil extract, marc (residues after oil extract) and extracts of active ingredients. Manufactured products with the ingredients of restricted plants are also increasingly being exported in the form of herbal tea, Ayurvedic medicines, nutrient supplements and tonics. Also, three species are banned for felling, transportation and export unless specified in the government-approved work plan: Shorea robusta (Sal), Dalbergia latifolia (Satisal), and Pterocarpus marsupium (Bijayasal). Government imposed restrictions on plants, however, do not prohibit any farmer or institution wishing to cultivate them in private land after seeking permission from the respective District Forest Office.

The MAP industry has been showing signs of growth in Nepal despite armed conflicts in the past. Numbers of traders and industries are increasing each year. As described above 90 percent of herbs leave Nepal in crude form, there is a vast potential for its processing in Nepal. The age-old government owned Singha Durban Vaidyakhana is manufacturing more than 100 Ayurvedic drugs and associated products. The first pharmaceutical industry of Nepal now utilizes about 200 medicinal plants, about 50 types of minerals, and animal products (SDVKVS 2004). The latest collection of herb-based marketing and processing company numbers 22, most of them focus on exporting oil extracts and semi-processed residues. If we consider NTFP as a whole, export of rosin and turpentine had been dominating the market, followed by other jadibuti. Increasingly, this year yarsa-gumba has greatly dominated the export market. Although not reflected in the government revenue because of uncontrolled international boarder to the north, it has been reported that the product is traded at as high as Rs. $900,000 / \mathrm{kg}$ at the local market. The product used to fetch an average of Rs. $100,000 / \mathrm{kg}$ only a few years ago.

Table 1 provides the statistics for the previous three consecutive fiscal years of the top 20 MAPs that were collected from government forests and highland pastures. Although these figures are considered only for government-managed forests, in reality, most of the products from private and community forests also become incorporated because many farmers prefer to pay royalty to DFO for plants grown in their farms and receive the transport permit in order to avoid hassles on their movement routes. The comparative analyses of jadibuti and "other NTFPs" for three consecutive fiscal years (Devkota 2006: table 1) show that there is a consistent increase in revenue from MAP/NTFP despite the armed conflicts in the country during the period. It must be borne in mind, however, that the revenue generated by NTFP represents only less than five percent of the total revenue of the Forest Department.

Table 1. Quantity and Revenue for selected 20 herbs (Jadibuti) found in Nepal

\begin{tabular}{|c|c|c|c|c|c|c|c|c|c|}
\hline \multirow[b]{2}{*}{$\mathrm{SN}$} & \multirow[b]{2}{*}{ Name of Jadibuti } & \multicolumn{2}{|c|}{$\begin{array}{l}\text { Fiscal Year } \\
2060 / 2061 \\
\end{array}$} & \multicolumn{2}{|c|}{$\begin{array}{l}\text { Fiscal Year } \\
2061 / 2062 \\
\end{array}$} & \multicolumn{2}{|c|}{$\begin{array}{l}\text { Fiscal Year } \\
2062 / 2063\end{array}$} & \multicolumn{2}{|c|}{$\begin{array}{l}\text { Fiscal Year } \\
2063 / 2064 \\
\end{array}$} \\
\hline & & $\begin{array}{c}\text { Quantity } \\
\text { Collected } \\
(\mathrm{kg})\end{array}$ & $\begin{array}{c}\text { Collected } \\
\text { Revenue } \\
\text { (Rs.) }\end{array}$ & $\begin{array}{c}\text { Quantity } \\
\text { Collected } \\
(\mathrm{kg})\end{array}$ & $\begin{array}{c}\text { Collected } \\
\text { Revenue } \\
\text { (Rs.) }\end{array}$ & $\begin{array}{c}\text { Quantity } \\
\text { Collected } \\
(\mathrm{kg})\end{array}$ & $\begin{array}{c}\text { Collected } \\
\text { Revenue } \\
\text { (Rs.) }\end{array}$ & $\begin{array}{c}\text { Quantity } \\
\text { Collected } \\
(\mathrm{kg})\end{array}$ & $\begin{array}{c}\text { Collected } \\
\text { Revenue } \\
\text { (Rs.) }\end{array}$ \\
\hline 1 & $\begin{array}{l}\text { Cordyceps sinensis } \\
\text { Yarsa gumba }\end{array}$ & 76.05 & $1,372,000$ & 12.60 & $2,52,060$ & 214.6 & $3,397,000$ & 254.1 & $2,540,600$ \\
\hline 2 & $\begin{array}{l}\text { Lichens } \\
\text { Jhhyau }\end{array}$ & 134,570 & $1,313,120$ & 102,131 & $1,000,315$ & 58,027 & 814,510 & 167,501 & $2,464,525$ \\
\hline 3 & $\begin{array}{l}\text { Nardostachys drandiflora } \\
\text { Jatamansi }\end{array}$ & 45,552 & 630,930 & 130,195 & $1,953,044$ & 687,113 & $1,554,075$ & 1,6471 & 247,065 \\
\hline 4 & $\begin{array}{l}\text { Orchids } \\
\text { Jiwanti }\end{array}$ & 32,557 & 102,615 & 31,973 & 143,119 & 16,133 & 48,799 & 4,375 & 15,600 \\
\hline 5 & $\begin{array}{l}\text { Aconitum spp } \\
\text { Bishjara }\end{array}$ & 35,809 & 243,944 & 41 & 410 & 9,894 & 67,749 & 8,595 & 60,165 \\
\hline 6 & $\begin{array}{l}\text { Swertia chirata } \\
\text { Chirayito }\end{array}$ & 169,703 & 481,628 & 125,244 & 357,693 & 45,949 & 527,890 & 50,155 & 729,045 \\
\hline 7 & $\begin{array}{l}\text { Neopicrorhiza scrophularififolia } \\
\text { Kutki }\end{array}$ & 5,200 & 32,920 & 10,586 & 103,583 & 11,082 & 110,820 & 13,364 & 133,640 \\
\hline
\end{tabular}




\begin{tabular}{|c|c|c|c|c|c|c|c|c|c|}
\hline 8 & $\begin{array}{l}\text { Morchella spp. } \\
\text { Gucchi chyau }\end{array}$ & 3,890 & 777,100 & 3,607 & 726,700 & 1,647 & 223,850 & 610 & 123,205 \\
\hline 9 & $\begin{array}{l}\text { Taxus wallichiana } \\
\text { Lauth Salla }\end{array}$ & 78,472 & $1,923,750$ & 160,197 & $4,004,935$ & 7,535 & 188,625 & 19382 & 208,562 \\
\hline 10 & $\begin{array}{l}\text { Pinus roxburghii } \\
\text { Khote Sallo }\end{array}$ & $3,836,183$ & $1,923,750$ & $1,888,134$ & $5,771,127$ & $4,091,748$ & $13,926,472$ & $5,520,096$ & $16,281,647$ \\
\hline 11 & $\begin{array}{l}\text { Terminilia chebula } \\
\text { Harro }\end{array}$ & 911 & 1,702 & 52 & 104 & 0 & 0 & 6,100 & 6,100 \\
\hline 12 & $\begin{array}{l}\text { Terminilia Bellirica } \\
\text { Barro }\end{array}$ & 95 & 190 & 3,043 & 6,086 & 0 & 0 & 3,450 & 3,105 \\
\hline 13 & $\begin{array}{l}\text { Sapindus mukorossi } \\
\text { Rithha }\end{array}$ & 420,436 & 907,719 & 899,061 & $1,782,157$ & 210,560 & 413,920 & 861,476 & $1,722,962$ \\
\hline 14 & $\begin{array}{l}\text { Emblica officianalis } \\
\text { Amala }\end{array}$ & 48,805 & 94,383 & 112,981 & 222,762 & 27,792 & 27,796 & 52,078 & 52,093 \\
\hline 15 & $\begin{array}{l}\text { Paris polyphylla } \\
\text { Satuwa }\end{array}$ & 11,235 & 56,021 & 1,740 & 8,700 & 21,992 & 110,610 & 808 & 7,480 \\
\hline 16 & $\begin{array}{l}\text { Zanthoxylum } \\
\text { Timur }\end{array}$ & 365,475 & $1,162,575$ & 429,140 & $1,286,620$ & 279,855 & $2,265,711$ & 460,710 & $3,670,040$ \\
\hline 17 & $\begin{array}{l}\text { Cinnamomum tamala } \\
\text { Tejpat }\end{array}$ & 33,455 & 336,631 & 9,355 & 87,260 & 114,180 & 228,360 & 50,974 & 101,969 \\
\hline 18 & $\begin{array}{l}\text { Cinnamomum } \\
\text { Dalchini }\end{array}$ & 1,035 & 20,700 & 1,729 & 17,290 & 32,068 & 320,690 & 18,279 & 660,484 \\
\hline 19 & $\begin{array}{l}\text { Valeriana jatamasi } \\
\text { Sugandhwal }\end{array}$ & 88,589 & $1,300,696$ & 47,549 & 61,3235 & 25,140 & 377,106 & 9,340 & 140,110 \\
\hline 20 & $\begin{array}{l}\text { Aconitum heterophyllum } \\
\text { Atis }\end{array}$ & 2,502 & 24,468 & 3,504 & 35,150 & 5,541 & 19,395 & 1,892 & 27,830 \\
\hline
\end{tabular}

To address the issues of MAPs and NTFPs in Nepal, the government has adopted the Herbs and NTFP Development Policy, 2061 (HMGN 2004). It has rightly emphasized conservation and sustainable utilization of NTFP, and simultaneously giving importance to commercial plantations. The development of this sector requires cooperation from other related sectors as well, especially industrial, finance, health and agriculture sectors. It is essential that large-scale commercial plantations of potential MAPs are done in private land, leased government land, community forests, and other public lands. This would then assure sustained supply of resources of required quality, which form the bases for any industrial growth. In this endeavour, government role would be to launch public awareness and extension programs, assistance in market development through programs like Nepal Standards, simplification of taxation modality, and providing easy access to accredited laboratories for quality certification.

Government of Nepal has identified 30 commercially important MAPs for further research and development and for development of agro-technology. Twelve of these plants are further identified for focused work (see Sharma et al. 2004). Initiatives such as reforming existing policies and laws that are adversely affecting the development of MAPs, establishing service centres for entrepreneurs, and launching massive awareness and training programs for farmers and officials alike, can help accelerate the process of commercialization of the MAP sector in Nepal.

MAPs can provide new opportunities to increase national income as well as the incomes of common farmers by many folds. The growth of many pharmaceutical and agrobased industries especially in the developed countries is the assuring sign that MAPs are going to be more valuable for their genetic materials and associated knowledge in the future. It is high time that Nepal keeps its policies favourable and create environment for new investments in this field in order to benefit from the developing world-wide demands for MAPs and associated products.

\section{REFERENCES:}

Amatya, K. R. 2000. Utilization of Himalayan Medicinal Plant Resources: Status, problems and Prospects. In: Proceedings of Nepal-Japan Joint Symposium on Conservation and Utilization of Himalyan Medicinal Resources, Nov. 6-11, 2000, Society for the Conservation and Development of Medicinal Plant Resources, Kathmandu, Nepal. Pp. 331-352. 
Bhattaria, N. K.; V. Tandon; and D. K. Ved. 2002. Highlights and outcomes of the Conservation Assessment and Management Planning (CAMP) Workshop, Pokhara, Nepal. In: Proceedings of the Regional Workshop held in Pokhara, Nepal 21-23 January 2001 on Sharing Local and National Experience in Conservation of Medicinal and Aromatic Plants in South Asia, edited by N. Bhattarai and M. Karki, IDRC South Asia Regional Office, New Delhi, India. Pp.46-53.

Community Based Economic Development (CBED). 1999. Subsector analysis of high altitude NTFPs in the Karnali Zone. NARMSAP (DANIDA-HMGN) and CIDA, Kathmandu, Nepal.

Department of Forests (DOF). Undated. Hamro Ban, annual report for Fiscal Year 2063/2064. DOF, Babarmahal Kathmandu, Nepal. (In Nepali)

Department of Forests (DOF). .........Hamro Ban , annual report for Fiscal Year 2062/2063. DOF, Babarmahal Kathmandu, Nepal. (In Nepali)

Department of Forests (DOF). 2006. Hamro Ban , annual report for Fiscal Year 2061/2062. DOF, Babarmahal Kathmandu, Nepal. (In Nepali)

Department of Forests (DOF). 2005. Hamro Ban , annual report for Fiscal Year 2060/2061. DOF, Babarmahal Kathmandu, Nepal. (In Nepali)

Devkota, B. 2006. Jadibuti tatha gairakastha banpaidawar samajik ra aarthik bikasko aadhar. In: Hamro Ban, annual report for Fiscal Year 2061/2062. DOF, Babarmahal Kathmandu, Nepal. Pp 88-113.

Government of Nepal, Ministry of Environment, Science and Technology (GOA). 2007. Notice of the government. Nepal Gazette, Khanda 57(19), 2064/5/3.

His Majesty's Government of Nepal, Ministry of Forests and Soil Conservation (HMGN). 2002. Nepal Biodiversity Strategy. Singha Durbar, Kathmandu, Nepal.

His Majesty's Government of Nepal, Ministry of Forests and Soil Conservation (HMGN). 1995. Forest Regulations, 2051, as amended. Nepal Gazette, Khanda 44 Atiriktanka $54,2051 / 12 / 20$.

His Majesty's Government of Nepal, Ministry of Population and Environment (HMGN). 1997. Environmental Protection Regulations, 2054, as amended. Nepal Gazette, Khanda 47, Atiriktanka 15 12/3/2054.

His Majesty's Government of Nepal, Ministry of Forests and Soil Conservation (HMGN). 2004. Herbs and Non-Timber Forest Products Development Policy. Singha Durbar, Kathmandu, Nepal.

Malla, S. B. and P. R. Shakya. 1984. Medicinal plants. In: Majpuria, T.C. (ed.), Nepal Nature's Paradise. White Lotus Co. Ltd., Bangkok, Thailand. Pp. 261-297.

Sharma, U. R., K. B. Malla and R. K. Uprety. 2004. Conservation and management efforts of medicinal and aromatic plants in Nepal. Banko Janakari 14(2):3-11.

Shrestha, T. B. and R. M. Joshi. 1996. Rare, Endemic and Endangered Plants of Nepal. WWF Nepal Program, Kathmandu, Nepal.

Singhadurbar Vaidyakhana Vikas Samiti (SDVKVS). 2004. Ayurvedic Products of SDVKS. Singha Durbar, Kathmandu, Nepal.

Acknowledgement: I would like to acknowledge the valuable contribution of Binod Devkota, Gopi P. Paudel and Nirmal Bhattarai in the preparation of this article.

008

The Initiation 2007 